\title{
COLLECTIVE EFFICIENCY AND SELECTIVE BENEFITS: THE GROWTH OF THE RATTAN INDUSTRY OF TEGALWANGI (INDONESIA)
}

\section{Ines Smyth}

\section{INTRODUCTION}

This article ${ }^{1}$ examines the small scale segment of the rattan industry of Tegalwangi (West Java, Indonesia), with the help of a new approach to the viability of small scale enterprises developed by Schmitz (1989) and based on the idea of collective efficiency. Taking a critical stance in relation to this approach, the article tries to:

- clarify that collective efficiency should not stand for forms of equalitarian relationships between firms of different size, in fact it views it as one of the mechanisms which can exacerbate economic differentiation between firms.

- stress that the segmented nature of the labour market encourages strategies on the part of firms which result in an unequal distribution of benefits among the different categories of labour.

These amendments do not undermine the validity of Schmitz's proposed approach, since they leave untouched its main premises: that small firms' capacity for growth cannot be achieved individually, but relies on the efficiency and flexibility made possible by geographical clustering and by division of labour between firms.

\section{THE RATTAN INDUSTRY OF TEGALWANGI}

In this section the main features of the industries producing rattan goods in the village of Tegalwangi are described, prioritising aspects which are relevant to the issues at hand.

Tegalwangi is a semi-urban village about $11 \mathrm{~km}$ from the town of Cirebon, on the north coast of West Java, with a population of 6,856 people (Bappeda 1988). Rattan blinds and chairs have been made in Tegalwangi since the 1930s. ${ }^{2}$ In the 1970s the industry experienced a period of growth, due especially to a number of institutional interventions by the Department of Industry, aimed at encouraging the growth of local small scale enterprises.

\footnotetext{
This is a much shortened version of a paper written in the context of the 'Productivity and Employment in the Non-Farm Sector of West Java' project, a cooperation between the Centre for Development Studies, Bogor Agricultural University, the Centre for Environmental Studies, Bandung Institute of Technologv, and the Institute of Social Studies, the Hague. As well as on the fieldwork by the author, the paper relied on the information gathered by several researchers involved in the project: 'Asih' Tiandraningsih, Dian Hanafiah, Rita Nasution, Lie Sing Tioe, Lola Wagner, Melani Abdulkadir, and Verdi Yusuf (see References), who kindly made
}

Tegalwangi also benefited from sectoral interventions for the rattan industry. These were intended to make the country internationally competitive in a sector in which it enjoyed a natural advantage, since Indonesia grows 80 per cent of world rattan and 56 per cent of all known species of the material (Kompas 15.1.89; Eksekutif 1989), but had little place in international markets for manufactured goods. In 1979 the government started passing legislation prohibiting first the export of unprocessed rattan cane, later of all export of basic rattan materials and, finally, of all semifinished rattan goods. Alongside these measures, special credit facilities have been made available for export.

The legislation was effective, as shown by the changes in the composition of Indonesian rattan exports between the years 1979 and 1987 :

\begin{tabular}{|lrrr|}
\hline \multicolumn{4}{|c|}{$\begin{array}{l}\text { Table 1: Composition of rattan exports } \\
(\%) \text { from Indonesia }\end{array}$} \\
\hline Type of export & 1979 & 1986 & 1987 \\
\hline Processed cane & 84 & 13 & 0.5 \\
Semi-finished goods & 15 & 85 & 95 \\
Finished goods & 1 & 2 & 4.5 \\
\hline Source: CIC 1988. & & & \\
\hline
\end{tabular}

The changes have had profound effects on the Tegalwangi industry: it is calculated that in 1978 there were 205 rattan producers, with a total labour force of 1,024 people, which increased to 323 and 3,192 respectively in 1985 , and to 399 and 6,840 to date (Bappeda 1988). The size structure of the local industry also changed. There are now 12 large scale enterprises (PUPUK 1988; Pykiran Rakyat 1989), oriented towards production for export, previously unknown. Considerable changes are also recorded in the relative proportions of the source of earning of the economically active population in the last decade. ${ }^{3}$

their findings available. Special thanks are due to Titi Setiawati who collaborated in fieldwork.

Some sources date the presence of rattan related activities to an earlier period, and precisely to 1916, when the Sultan of Cirebon was still reigning (Gema 1980).

${ }^{3}$ A certain amount of caution should be used in reading such data. Longitudinal comparisons are particularly difficult in this case, since the administrative boundaries of the vilage have been changed. 


\begin{tabular}{|c|c|c|}
\hline \multicolumn{3}{|c|}{$\begin{array}{l}\text { Table 2: Relative distribution of main } \\
\text { source of earning (\%) in } \\
\text { Tegalwangi }\end{array}$} \\
\hline & 1977 & 1988 \\
\hline Agriculture & 50 & 14 \\
\hline Rattan Industry & 22 & 65 \\
\hline Trading & 20 & 20 \\
\hline Others & 8 & 1 \\
\hline \multicolumn{3}{|c|}{ Sources: Laporan 1977; Monografi Desa 1989} \\
\hline
\end{tabular}

Another change which has taken place is the geographical expansion of the industry: one third of all enterprises are in Tegalwangi itself, the rest are now in the surrounding villages (Bappeda 1988:17). One interesting aspect of this situation is that workers from Tegalwangi have obtained a position of privilege: they are given priority in allocation of jobs and are paid higher wages.

The industry produces goods such as chairs, racks (for newspapers, linen, magazines, shoes), stools, tables and basketry, in a great variety of models. Most goods are sold abroad, to Japan, Australia and some European countries, via the 12 local larger enterprises or via exporting firms based in Jakarta or other cities. A smaller proportion of the goods is sold to national markets or directly in the 30 or so local shops-showrooms.

For the purposes of this article we distinguish beween three types of small-scale enterprises:

- enterprises with direct access to raw materials and consumer markets. They vary from those using paid and unpaid family labour, ${ }^{4}$ one or two workers, to those who employ up to 20 paid workers. They often sub-contract parts of the work to homeworkers and workshops.

- enterprises which have no direct access to consumer markets and operate exclusively under subcontracting arrangements, manufacturing componenets of goods or performing one or more stages in the labour process. Raw materials are bought locally and on credit. ${ }^{5}$ Their internal organisation also varies considerably, as does the amount of work which, in their turn, they put out.

- homeworkers: these are individuals who perform very specific and limited tasks with materials entirely provided by other firms, to which goods are returned within a stated period. Additional household members, including children, contribute to the work.

\section{EXPERIMENTING WITH A NEW APPROACH}

For a long time now the study of the viability of small scale industries has been marred by theoretical and methodological problems. The objective of this section of the article is to experiment with a new approach, which offers the possibility of overcoming some of these problems. Schmitz (1989) has set the terms of this new approach through a selective and critical reading of the basic text on flexible specialisation by Piore and Sabel (1984).

It would be impossible here to do justice to the merits and problems of the debates which have developed around the concept of flexible specialisation (for critical reviews see Pollert 1988; Williams et al 1987). ${ }^{6}$ It would also be beyond the scope of this article, since Schmitz focuses on that part of the flexible specialisation debate which is concerned with small scale industries: 'One can distinguish a small and large firm variant of flexible specialisation . . . Our main interest lies in the small firm variant, where flexible specialisation results from the clustering of small firms and a strong inter-firm division of labour.' (Schmitz 1989:10)

Collective efficiency is the concept central to the proposed approach to small scale enterprises' viability, and reflects the idea that competitiveness cannot be achieved by individual firms but relies on two elements: physical agglomeration and sectoral specialisation. Such clustering provides small enterprises with networks through which they have access to essential raw materials and machinery. In addition, according to $S c h m i t z$, the presence in most developing countries of abundant labour encourages forms of competition which rely on minimising rewards for labour, while not entirely preventing innovation. These, schematically, are the main elements of the view proposed by Schmitz. In what follows, some aspects of these views are chosen for closer scrutiny.

\subsection{Collective efficiency and uneven benefits}

This and the next section suggest that the new focus on collective efficiency has a number of advantages, but it runs the risk of losing sight of the uneven character of the benefits derived from it: uneven to both different kinds of enterprises (this section) and different categories of labour (Section 3.2).

\footnotetext{
${ }^{4}$ It is often assumed that family labour is always unpaid. Here the work of children is of ten remunerated, as is that of other members of the family. Husband and wife, however, are not paid separately for their work.
}

\footnotetext{
${ }^{5}$ Credit is ensured by a 'bon', a chit provided by the parent firm to the sub-contractor.

${ }^{6}$ The article by Schmitz on which this article is based has a comprehensive bibliography on flexible specialisation.
} 
Clustering brings advantages to the small scale enterprises of Tegalwangi in many ways. The historical concentration of rattan firms in the area of study has attracted the initial policy interventions from which many of the later developments stemmed. This is because the Indonesian regional offices of the Department of Industry enumerate small scale enterprises and plan their interventions around socalled 'centres' (Dinas Perindustrian 1989), thus a degree of concentration of activities is a pre-condition for assistance.

Agglomeration means that raw materials are readily available to small producers. Rattan is brought in from the distant islands of Kalimantan and Sumatra. Prices charged by local traders are higher than those imposed by outside merchants, but credit concessions make them accessible to producers with little capital.

For small scale producers proximity to each other also means the possibility of utilising more advanced machinery. For instance, one very small producer interviewed is able to produce semi-finished goods for a large exporter thanks to his access to a 'steamer' (to bend the larger rattan canes into frames) owned by a neighbour.

Physical proximity facilitates transportation. ${ }^{7}$ Small producers make use of traditional means of transport such as bicycles, hand carts and pedal rickshaws to carry materials, parts and finished goods, which could not be employed if distances were greater.

The flow of information concerning demand, prices and levels of wages is also facilitated by the geographical concentration of small firms. This is compounded by the fact that Tegalwangi is not an industrial estate separated from the community, rather is a mixture of the two where, as Piore and Sabel put it: 'it is hard to tell where society (in the form of the family and school ties or community celebrations of ethnic and political identity) ends, and where economic organisation begins (1984:275).

Indeed in Tegalwangi neighbours are related by ties of kinship, making the overlap between community and economy even more complete. Skill transmission too, is an integral part of family and neighbours' daily exchanges, and it is made easier by proximity. The importance of this informal training receives recognition by the higher wages paid to workers originating from the village.

It would seem that clustering allows flexibility and efficiency for small scale industries, in the way suggested by Schmitz. However, Tegalwangi has seen the rise of a number of large firms which occupy a different position in inter-firm relations and which, as a consequence, may derive much greater benefits from agglomeration than their small counterparts. In the remainder of this section, the question of the relative advantages from sub-contracting are discussed, since this is the most common form taken by inter-firm relations.

Sub-contracting is not new in Java, nor in Tegalwangi. Among the large local exporters of rattan products sub-contracting accounts for varying proportions of the total volume of production, from 30 to 80 per cent. There are three forms of sub-contracting in Tegalwangi:

- of semi-finished goods,

- of components and

- of a stage(s) of the work.

In some instances chains of sub-contracting are formed, from large exporter, to medium or small scale enterprise, to homeworkers, where all three types of sub-contracting are used. In general, verbal but binding contractual agreements are made between parent and sub-contractor defining its terms: tasks, rates for the job, delivery date. For each contract the parent firm pays an advance (uang muka = opening money) of around 25 per cent of the value of the total order, with which the sub-contractor pays his/her labour force and/or those below in the sub-contracting chain. With the exception of home-workers, to whom all materials are provided, sub-contractors have to acquire rattan for themselves, on credit from local traders.

While some small scale entrepreneurs who have subcontracting relations with exporters are the owners of long established concerns, others are former wage workers who have set up their own businesses at the initiative of the ex-employer. The initial activities of the new enterprise are made possible by the orders from the former employer, by credit for raw materials, and by the 'uang muka'.

This description leads to a discussion of relative benefits of sub-contracting for large exporters and small scale enterprises, essential for a critical evaluation of collective efficiency. Presumably the fact that subcontracting relations have survived and expanded imply that they offer certain advantages to those involved. For the large scale enterprises, putting out orders to smaller entities offers the kind of benefits often remarked on in the relevant literature (Watanabe 1971; Schmitz 1982):

a Demand for Tegalwangi rattan furniture is not constant. Local firms prefer to counter fluctuations

\footnotetext{
Mead (1984:1098) makes this point for the transportation of goodsin-process, especially when they are bulky, which is certainly the case for most rattan goods.
} 
in demand with a disintegrated organisation of production. This however is not the only strategy they adopt in response to changeable levels of demand: according to local sources dismissal of workers is a common feature in the industry. This is made possible by the poor protection enjoyed by local workers, not only as a result of the political context of Indonesian labour relations, but also of the paternalistic nature these have in Tegalwangi.

b A second advantage for large firms is still related to the nature of demand. Export orders have to be completed within set time limits. The speed at which orders are finished can be enhanced by subcontracting, which avoids overtime among waged workers and the need to keep stocks of raw materials or of finished goods, the price of which may fluctuate. Speed can be manipulated particularly when the chain of sub-contracting includes the third category of small scale industries, i.e. homeworkers, since the latter often increase their output by involving more members of the household in the work.

c A third advantage also relates to the nature of demand. Orders are for a great variety of goods; sub-contractors become specialised in a number of specific goods, in the production of which they acquire considerable speed. Parent firms place orders according to such specialisation, thus maximising both speed and quality of product.

d A final advantage for parent firms is related to the fact that in Tegalwangi space is at a premium: rattan goods are mostly bulky, and the price of land is very high, ${ }^{8}$ making expansion an expensive option. ${ }^{9}$ Though physical expansion takes place, subcontracting shifts the problem of space to the subcontractors, at least to some extent.

What are the benefits for the small sub-contractors?

a Access to foreign, and indeed any markets, is the first obvious benefit enjoyed by small scale enterprises.

b Even more important is the ability to obtain raw materials on credit, and working capital via the advances paid by parent firms.

c Sub-contracting also offers benefits for older men and women for whom wage work is not an option because of employers' recruitment practices which favour the faster and more easily trained younger workers. Sub-contracting is the obvious way to remain economically active where other employment opportunities have virtually disappeared because of the 'monocultural'10 nature of the environment.

${ }^{8}$ Land in Tegalwangi is sold for up to Rp 25.000 per square metre, while in nearby villages it is rarely more than $\mathrm{Rp} 10.000$ (from an interview with the village Head).

${ }^{9}$ This raises a separate issue of considerable importance: that of the
It should be clear from the above descriptions that both large parent firms, and small sub-contractors benefit from such relationships. But despite the mutual benefits of sub-contracting arrangements, the relationship between enterprises of different size and different character is one of control on one side and dependence on the other. This is reflected by the fact that most small scale enterprises, namely those classified under the second and third types, entirely depend for their survival on remaining linked to one or more large or medium exporters, since from them comes the capacity to obtain raw materials, working capital and access to markets. Large scale exporters rely on a number of trusted sub-contractors, but the sheer number of the latter enhances the negotiating position of the former. Furthermore, sub-contracting is one of several options open to large firms, as shown earlier.

Agglomeration can be seen to be advantageous to the rattan industry as a whole, and collective efficiency to be a characteristic of this branch of the Indonesian manufacturing industry. However, in the context of a differentiated industry, where firms of different size exist and sub-contracting is the most common link between them, some are in a more powerful position than others. This amounts to saying that collective efficiency has different meanings for firms in different positions. Schmitz's notion of collective efficiency emphasises the mutual benefits of clustering, thus losing sight of differentiation within the cluster. To conclude, the experience of the rattan industry of Tegalwangi, suggests that:

- sectoral agglomerations include firms which are in hierarchical relations to each other;

- while the relative position in the hierarchy may be changeable, economic differentiation increases over time, making the benefits from collective efficiency more and more skewed.

\subsection{Social differentiation}

The previous section stressed the differentiation among enterprises. This section shows that, because local economy and community overlap so much, there is also a process of social differentiation: the benefits which the different categories of labour derive from the growth of the local economy are uneven.

Labour markets are always segmented and the categories which rule the attribution of certain people to given tasks in Tegalwangi are those of gender, age and place of origin:

\footnotetext{
changes in the agrarian structure of the area.

${ }^{10}$ This is the term used by Solinas (1982:332).
} 
Gender: each task is gender specific. Women are responsible for tying, weaving and sometimes sanding, in large and in small firms; these tasks are consistently paid lower rates" than those of men, though they are rarely performed by male workers.

Age: is also a differentiating element, children and very young workers performing tasks such as sanding and packing, are paid at very low rates. But age plays a role in another way, i.e. in allocating labour to different categories of enterprises, as well as to different categories of skills. In large enterprises skilled workers are relatively young, since younger workers are deemed to be more easily adaptable to the routine of factory work. Age also combines with gender so that, for example, many homeworkers performing tying work are older, married women, whose household and childcare responsibilities hinder (though not always prevent) factory employment.

Place of origin: works in determining levels of wagerates rather than in the allocation of tasks. As already explained, workers from Tegalwangi are considered more skilled than those from adjoining villages, thus they are able to obtain higher piece-wages. Because of the higher rates demanded by local workers, it is common for small entrepreneurs to employ workers from outside who, though cheaper, have less skills and experience.

Categories of labour exist as social categories, before and independently, of the economic functions they perform in this context. Firms of all sizes make use of them to their advantage, re-shaping and reproducing them. Small scale firms cannot compete with larger ones by innovating either their organisation of production or the technology they employ. Other mechanisms have to be devised to ensure the survival and reproduction of the enterprise. Such solutions minimise rewards for labour by making use of the segmented nature of the labour market. Small scale industries rely on:

a employing labour from the cheaper segments of the market, for example younger workers (often children) and workers from outside Tegalwangi;

b using forms of unremunerated labour through the apprenticeship of young neighbours and relatives;

c increasing self-exploitation through extending the working hours of family labour and increasing the number of members of the family involved in production.
While it is undeniable that in quantitative terms there has been an increase in employment opportunities, the differential access which various categories of people (by sex, age and place of origin) have to different jobs and to different types of enterprises, their uneven levels of remuneration and their varying degrees of security and regularity have social consequences which the concept of collective efficiency obscures.

\section{CONCLUSIONS}

The above analysis of the rattan industry of Tegalwangi has tried to bring to the fore two issues:

1 The importance of stressing that collective efficiency does not mean the absence of differentiation among firms. Beyond the differences in scale of enterprises, in sub-contracting and other relations large firms retain better bargaining positions, as well as receiving benefits from small ones, for example in the form of trained workers.

2 There is also differentiation among workers due to a segmented labour market. Firms of all sizes try to minimise labour costs resulting in an uneven distribution of the benefits of the expanded employment opportunities among the various categories of workers.

While the class differences emerging in Tegalwangi have long term social and economic consequences difficult to establish here, the differential access to positions and to jobs with very unequal status and remuneration, is reflected in the superior wealth displayed by some individuals and households.

We can conclude that in Tegalwangi the agglomeration of firms is indeed resulting in collective efficiency which, together with public intervention at several levels, has made it possible for the rattan industry to expand considerably. At the same time an analysis of the differentiated nature of the industry reveals that the benefits of such growth accrue differently to firms of different size and nature. Furthermore, the existence of a segmented labour market and its uses for lowering labour costs, have uneven consequences for the individuals involved in it as entrepreneurs and as workers. While the overall value of readily available employment in the area cannot be underestimated, the polarisation of wealth and the absence of substantial improvements in the living conditions of the majority of the population should indicate that collective efficiency does not necessarily correspond to equal distribution of benefits.

\footnotetext{
"In firms of all sizes all types of work are paid by piece rates, and rates are fairly standard across firms, though large firms tend to pay higher rates.
} 


\section{REFERENCES}

Bappeda Kabupaten DAT III Cirebon, 1988, Desa Tegalwangi Kec. Weru, Kab. Cirebon Sebagai Pusat Pertumbuhan Daerah, Pedesaan

CIC (Capricorn Indonesia Consult), 1988, A Study on the Prospects of the Rattan Industry and Market, Jakarta

Dinas Perindustrian, 1989, 'Perkembangan sentra industri kecil rotan Tegalwangi'

Kompas, 1988: 26th September, 10th October, 17th October, 26th October, 23rd December; 1989: 15th January, 18th January

Eksekutif, 1989, April

Gema Industri Kecil, 1980/81 'Kesempatan Usaha Bidan Industri Kecil Kerajinan Rotan', Vol 5

Hanafiah, D., 1989, 'Pelaksaanan Sistim Sub-Contract Pada Industri Rotan Tegalwangi', Jurusan Ilmu-Ilmu Sosial Economi Pertanian, Facultas Pertanian, IPB, Bogor

Laporan Sementara Hasil Penelitian Fungsi Pusat Pelayanan Industri Kecil and Keraiinan Rotan di Tegalwangi, Cirebon, 1977

Mead, D. C., 1984, 'Of contracts and sub-contracts: small firms in vertically dis-integrated production/distribution systems in LDCs' World Development, Vol 12 Nos $11 / 12$

\section{Monografi Desa Tegalwangi, 1989}

Nasution R., 1989, 'Analisis Kesempatan Kerja dan Pendapatan Industri Rotan', Program Studi Ekonomi Sumberdaya, Jurusan Ilmu-Ilmu Sosial Ekonomi Pertanian, Facultas Pertanian, IPB, Bogor
Pykiran Rakyat, 1988: 11th April, 23rd March, 3rd November, 15 th December, 19th December, 23rd December. 1989: 4th April

Piore, M. J. and Sabel, C. F., 1984, The Second Industrial Divide, Basic Books, New York

Pollert, A., 1988, 'Dismantling flexibility' Capital and Class, No 334, Spring

PUPUK (Perkumpulan Untuk Peningkatan Usaha Kecil), 1988, Laporan Penelitian Sentra Industri Kecil Rotan di Tegalwangi, Cirebon

Schmitz, H., 1982, Manufacturing in the Backyard, Pinter, London

-1989, 'Flexible specialisation: a new paradigm of small-scale industrialisation?' Discussion Paper 261, Institute of Development Studies, Sussex

Sing Tioe L. and Wagner, L., 1989, Study on Pupuk, Preliminary Report

Solinas, G., 1982, 'Labour market segmentation and workers' careers: the case of the Italian knitwear industry', Cambridge fournal of Economics, Vol 6

Tjandraningsih, I., 1989, Tenaga Kerja Anak dan Remaja Dalam Industri Rotan Tegalwangi di Cirebon, Laporan Sementara

Watanabe, S., 1971, 'Subcontracting, industrialisation and employment creation', International Labour Review, Vol 104

Williams, K., Cutler, T., Williams, J., Haslam, C., 1987, 'The end of mass production?', Economy and Society, Vol 16 No 3

Yusuf, V., 1989, Fieldnotes, Tegalwangi, Cirebon 